\title{
UNDERSTANDING FLOW OF CARBON AND NITROGEN IN MALAYSIAN SANITARY LANDFILL
}

\section{Venu Mahendra MS., Mohd Afzanizam M. \& Agamuthu P.*}

Centre for Research In Waste Management

A307 Block A Level 3 Insititute of Postgraduate Studies

University of Malaya 50603 Kuala Lumpur Malaysia

\section{*Corresponding author email agamuthu@um.edu.my or tel. +603 79674631}

\begin{abstract}
Landfill can be an artificial carbon sink; accumulates and stores carbon-containing chemical compound for an indefinite period. Landfill posed risks of undesired environmental impacts due to the generation of leachate and gases namely carbon dioxide, $\mathrm{CO}_{2}$ and methane, $\mathrm{CH}_{4}$ with trace amounts of nonmethane organic compounds (NMOC) that include air pollutants and volatile organic compounds. Elements were selected based on environmental matrix and importance as raw materials with definite negative effects. In 2009, Jeram Sanitary Landfill received 730,547.79 metric tonne of waste from Kuala Lumpur and Selangor municipalities. Jeram Sanitary Landfill (JSL), as located in area of tropical country receives high amount of precipitation, about $1900 \mathrm{~mm}$ to $2000 \mathrm{~mm}$, contributing to significant intrusion of acid deposition such as carbon monoxide, $\mathrm{CO}$ and nitrogen oxides, NOx. The quantity of leachate generated reflects the performance of landfill based on water balance components which include surface runoff, evapotranspiration, lateral drainage and leachate generated. Material Flow Analysis was realised using quantified possible inputs and outputs in elementary level. Kitchen waste and garden waste contributes significantly to the mass flow in landfill, indirectly contrubuting to source of organic carbon and total nitrogen in landfill. Carbon was predominantly exported in gas form whereas for nitrogen, the major pool was found in the atmosphere. The atmospheric pool of nitrogen was found coupled to the biogeochemical cycle, influenced by microbial nitrogen fixation and denitrification.
\end{abstract}

(Keywords: landfill, carbon, nitrogen, material flow analysis, waste)

\section{INTRODUCTION}

Malaysia, similar to any tropical country, faces a common trend of high wet valued wastes. Thus, need for proper and organised waste disposal method is a challenge, with the increament in both population and overall waste. Moreover, if not managed well, it can contribute towards negative complexicity such as industrial pollution and degradation of the urban environment. Local authorities are the major key stateholders responsible for spatial planning, environmental planning, waste management, sewage treatment, and supervision of various industrial activities in the municipal territory (Lindqvist. 2004). A prerequisite for sensible waste planning and rational evaluations of future environmental problems is the availability of reasonable projections of material usage and waste generation (Andersen et al., 2006). Sorting with various angles would give a challenge in selecting the best management option without quantification and qualification of the waste end life option. The best and common practice of waste end in Malaysia is landfill.

Looking into complex system such as landfill, Material Flow Analysis (MFA) provides information on the fluxes of resources used and transformation pathways as it flow through a region (Brunner. 2004). MFA is proved to be a suitable instrument for early detection of environmental problems and development of appropriate measures in industrialized countries (Baccini. 1996). MFA has already been integrated in urban areas of developing countries in the field of environmental sanitation (Binder, 1996; Belevi, 2002; Montangero et al., 2004; Huang et al., 2006). Bergback et. al (2001) studied material flow of several metals such $\mathrm{Cd}$ and $\mathrm{Cr}$ in Stockholm, Sweden. The flow of $\mathrm{Cu}$ in Europe was investigated by several studies through a lifecycle from extracting ore, through processing and manufacturing, to solid waste management or recycling (Graedal et.al.,2002; Spatari et.al.,2002; Bertram et.al., 2002).

Connecting the sources, pathways, intermediate and final sinks of a material given account to MFA to systematically asses the flows and stocks of materials within a defined system. It is an accounting system that captures the mass balances in relevance to both environment and economic interest, where inputs (extractions + imports) equal outputs (consumptions + exports + accumulation + wastes). It is this distinct characteristic of MFA that makes the method attractive as a decision-support tool in resource management, waste management and environmental management (Brunner. 2004).

In the air, excess reactive nitrogen contributes to higher levels of ozone in the lower atmosphere, 
causing respiratory ailments and damaging vegetation. From the atmosphere, nitrogen falls to the surface, generating a series of effects such as corrosion of buildings, bridges and other humanmade structures, acidification of soils and water bodies, and inadvertent fertilization of trees and grasslands, creating unnatural growth rates, nutrient imbalances, and decreasing biodiversity.

Leaching out of the soils, reactive nitrogen can make ground water and surface water unfit for human consumption. Nitrogen atom that starts out as part of a smog-forming compound may be deposited in lakes and forests as nitric acid, which can kill fish and insects. Carried out to the coast, the same nitrogen atom may contribute to red tides and dead zones. Reactive nitrogen also promotes eutrophication in coastal ecosystems, which deteriorates fish habitat and aquatic biodiversity. Eventually, most reactive nitrogen is converted back to harmless nitrogen gas by soil and aquatic bacteria called "denitrifiers", but a portion is converted to nitrous oxide, which contributes to both the greenhouse effect and to stratospheric ozone depletion. Once released into the environment, nitrogen cascades from one negative environmental impact to another.

Carbon (C) as the organic is a main component of biogenous goods, a main carrier of chemical energy and a basic element of toxic substances ( $\mathrm{CO}$ and $\mathrm{CN}$ ) It is both a vital substance energy (conversion by microorganisms), and in different Compounds a polluting pollutant. Carbon is an essential element of the biosphere and in all living things. Studies that relate to specified emissions to the production of base materials or to various sectors of industry lead to the next type of accounting (Bringezu et al., 1997). Carbon is a versatile element which has ability to bind with most molecules or compounds, even commonly free-binding with organic materials.

Carbon is also very much used in global scale as a subsidiary in daily anthropogenic activities such as fuel, food, buildings and others. These common activities will lead to end value of carbon as waste in landfill, as the most widespread disposal method. (Baccini. et al., 2010) The dilemma begins when carbon discharged to environment as not knowing the process or pathway of transformation, either to state of dormant or affecting form with surroundings. Therefore, this element is foreseen as a silent threat to our current environment. This research aims to seek detailed input and outputs of materials in landfill with quantified values contributing to environment degradation. It is also aimed to discuss the proscpects of the values in potrayal of complete elemntary flow diagram.

\section{MATERIALS AND METHOD}

\section{The Landfill Description}

The sampling was carried out between November 2009 and June 2010 at Jeram Sanitary Landfill. The landfill is located at Lot No. 1595, 2958 and 2959 in Jeram Town, Kuala Selangor District, as shown in figure 1. The land was previously used as agricultural land. The landfill is under privatisationcum-concession for the construction, operation and maintenance of a 160- acres area. The average receiving capacity of waste is 2100 tonne per day. The types of waste received are domestic waste, bulk waste and garden waste. The landfill caters 7 major municipalities in Klang Valley namely Kuala Selangor, Subang Jaya, Klang, Petaling Jaya, Shah Alam, Ampang Jaya and Selayang. Jeram Sanitary Landfill started its operation on $1^{\text {st }}$ January 2007 with 16-years of expected lifespan, depending of the amount of wastes received.

Methods and Apparatus

\section{Analysis of Waste Composition}

Waste segregation was done to determine quantity and quality of waste composition deposited at the landfill sites. The segregation work done by sorting the waste according to the classification by Tchobanoglous et. al. (1993). This was done by separating waste delivered to the sites into four portions and each portion was further divided into another four portions until the weights of each portion was around $100 \mathrm{~kg}$. The loadings come from medium-sized compactor. The solid waste samples are taken at random from current active cells. Samples were analysed based on test parameter as shown in Table 1.

\section{Gas Measurement}

Gas reading taken from each landfill site was conducted in-situ using a portable multi-gas analyser (Gas Alert Microclip). The sensor type of the analyser is plug-in electrochemical cell for hydrogen sulphide, $\mathrm{H}_{2} \mathrm{~S}$, carbon dioxide, $\mathrm{CO}$ and oxygen, $\mathrm{O}_{2}$ and catalytic bead sensors for combustibles. The $\mathrm{O}_{2}$ measuring principle is based on capillary controlled concentration sensor. Sample of gas were also captured using Tatler Bag at the valve tip of gas well and gas flaring unit. It was then analysed in the labarotary to determine concentration using Gas Chromatograph (Model GC-8A Shimadzu). The gas flow rate was based on daily estimation of the emission. The data collected in-situ includes methane, carbon dioxide, carbon monoxide, hydrogen sulphide and ammonia. Other parameters that were recorded are ambient temperature, relative humidity and rainfall. 


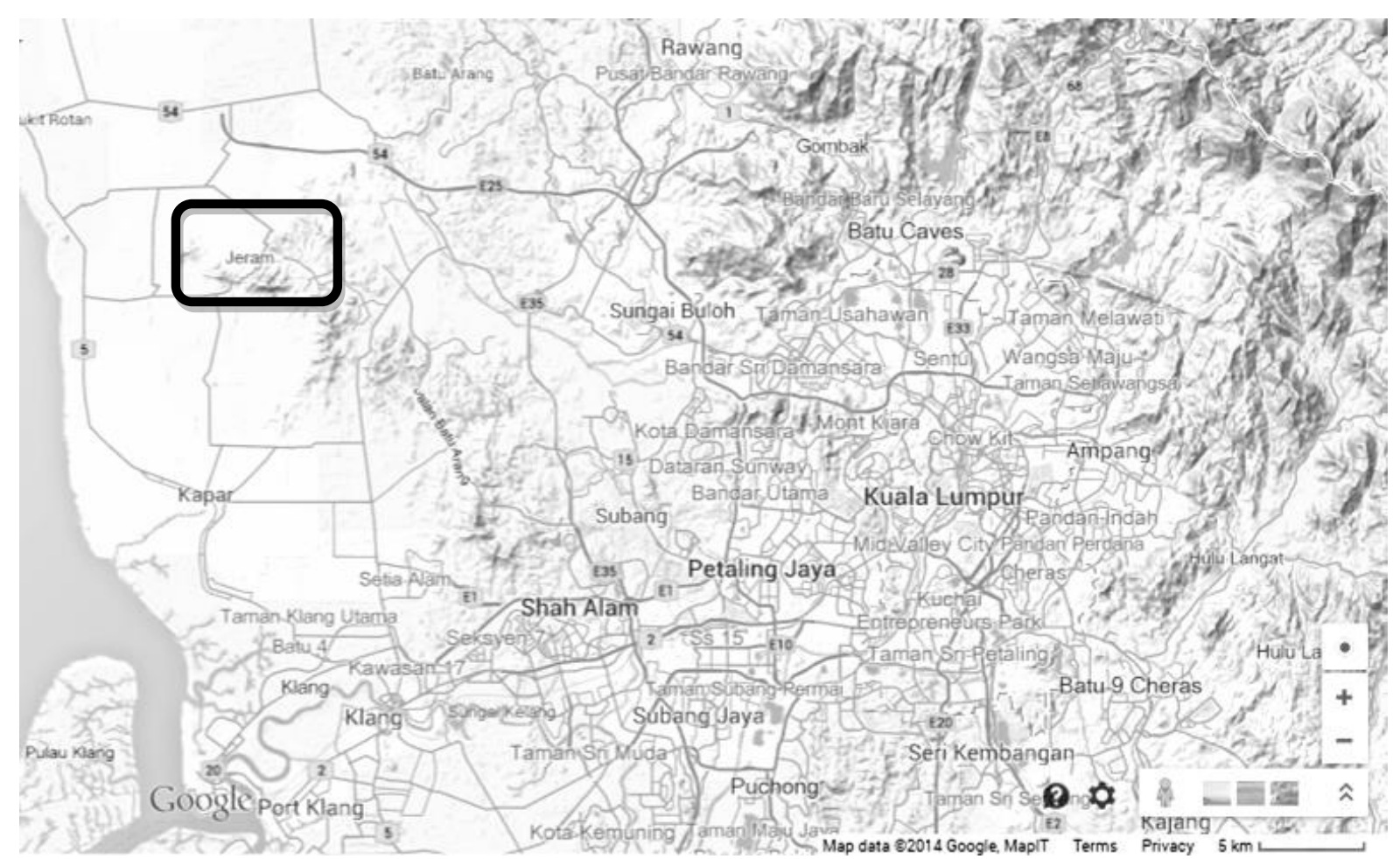

Figure 1: Map showing the location of Jeram Sanitary Landfill. Source: Google Maps@.

\section{Gas Measurement}

Gas reading taken from each landfill site was conducted in-situ using a portable multi-gas analyser (Gas Alert Microclip). The sensor type of the analyser is plug-in electrochemical cell for hydrogen sulphide, $\mathrm{H}_{2} \mathrm{~S}$, carbon dioxide, $\mathrm{CO}$ and oxygen, $\mathrm{O}_{2}$ and catalytic bead sensors for combustibles. The $\mathrm{O}_{2}$ measuring principle is based on capillary controlled concentration sensor.
Sample of gas were also captured using Tatler Bag at the valve tip of gas well and gas flaring unit. It was then analysed in the labarotary to determine concentration using Gas Chromatograph (Model GC-8A Shimadzu). The gas flow rate was based on daily estimation of the emission. The data collected in-situ includes methane, carbon dioxide, carbon monoxide, hydrogen sulphide and ammonia. Other parameters that were recorded are ambient temperature, relative humidity and rainfall.

Table 1: Test parameter for waste samples from Jeram Sanitary Landfill

\begin{tabular}{|l|l|}
\hline Test Parameter & Test Method \\
\hline Total Organic Carbon (TOC) & APHA 5310 B \\
\hline Inorganic Carbon & ASTM E 949 \\
\hline Total Nitrogen & ASTM E778-87 \\
\hline Ammoniacal Nitrogen & APHA 4500 NH3 B\&C \\
\hline Organic Nitrogen & APHA 4500-N org $_{\text {Kjeldahl Method }}$ \\
\hline Inorganic Nitrogen & APHA 4500-N ${ }_{\text {inorg }}$ Kjeldahl Method \\
\hline
\end{tabular}

\section{Soil Sampling}

On each sampling occasion five, 5 soil samples were collected from random points of designated lots using shovel to fifteen, $15 \mathrm{~cm}$ deep (Refer figure 2). Soil sample taken were topsoil and semi- marine clay. The soil was then dried at $45^{\circ} \mathrm{C}$ for 3 days and powdered in laboratory using pestle and mortar. Element analysis done for main nutrient and trace nutrient for $\mathrm{P}, \mathrm{K}, \mathrm{Mg}, \mathrm{Ca}, \mathrm{Mn}, \mathrm{Al}$ and $\mathrm{Fe}$ using ICP-OES machine. 


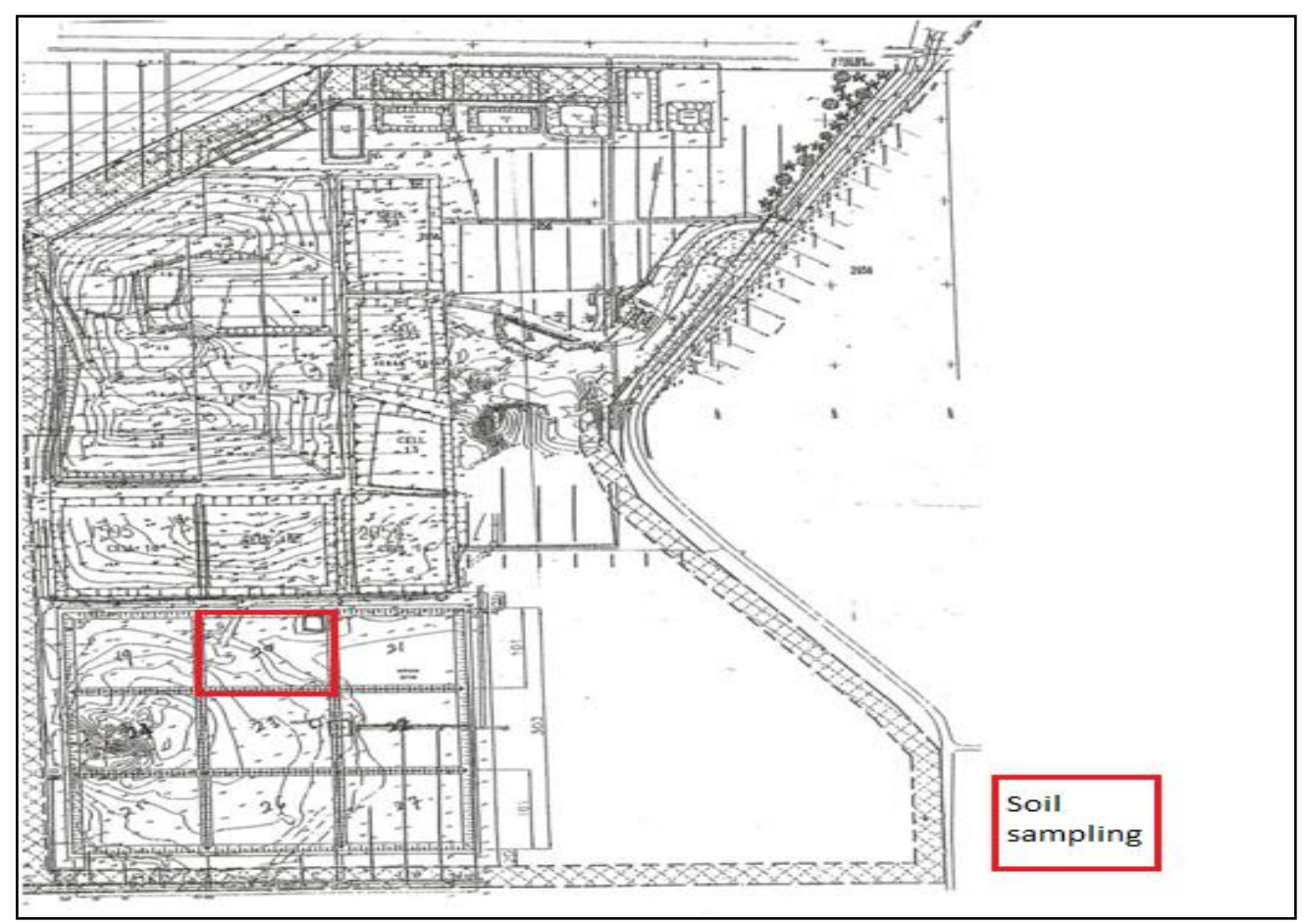

Figure 2: The map shows sampling location for solid waste and soil in Jeram Sanitary Landfill.

\section{Rainfall Data}

Quality and quantity rainfall in Jeram Sanitary Landfill is acquired. The nearest station is Mardi Tanjong Karang Latitude $3^{\circ} 28^{\prime} \mathrm{N}$, Longitude $101^{\circ}$ $08^{\prime}$ E. The Mean Sea Level (MSL) is $2.4 \mathrm{~m}$. JSL received total rainfall amount $1974.7 \mathrm{~mm}$ in 163 raindays whereas from January to July 2010, total rainfall amount was $1007.5 \mathrm{~mm}$ in 106 raindays. The daily rainfall amount for a particular day is the amount collected over the 24-hour period beginning from 8.00 am (0800 Malaysian Standard Time) on the day. An assessment of acid deposition was done in reference to the Time Series Data

\section{Calibration of ICP-OES}

Initial calibration were done with a minimum of one calibration blank and five calibration standards ; 1 ppm, 2ppm, 3 ppm, 10 ppm, 20 ppm of 13 analytes. The number of calibration points depends on the width of the dynamic range and the shape of the calibration curve. The differences between calibration standard concentrations was set not be greater than one order of magnitude (i.e $1,10,100,1000)$. A Method Blank (MB), also known as reagent blank is a portion of reagent water treated exactly as a sample, including exposure to all equipment, glasswares, procedures and reagents. The MB is used to assess whether analytes or interference are present within the analytical process or system. MB was used as a standard reference portion of standard comparison used.
Analysis for the Annual pH (1994-2008) central part of Peninsular, Petaling Jaya, which indicated as being area with $\mathrm{pH}$ value of rainfall ranging from 4.2 to 4.6 .

\section{Leachate collection}

Leachate was collected from Lagoon 1 of the leachate holding pond and kept inside Schoot bottle. Digestion and element analysis was done $e x$ situ. These elements are Total Organic Carbon, inorganic carbon, ammonia nitrogen, organic nitrogen, inorganic nitrogen.

\section{Material Flow}

Spatial boundary for this study was one year. Presentation of product and material flows using the method of material flow analysis was done with mapping details from previous steps. The software STAN (Substance Flow Analysis) was used to potrayed a clear display of product and material balances. The evaluation criteria (raw data of inputs and outputs) was performed by using Excel spreadsheets. Goods and hazardous substances quantified and accounted for the processes within that system. Input values includes rainfall, waste loading with soil (as sink) and output values includes gas emmisions, leachate and again soil (as sink) (Refer figure 3). 


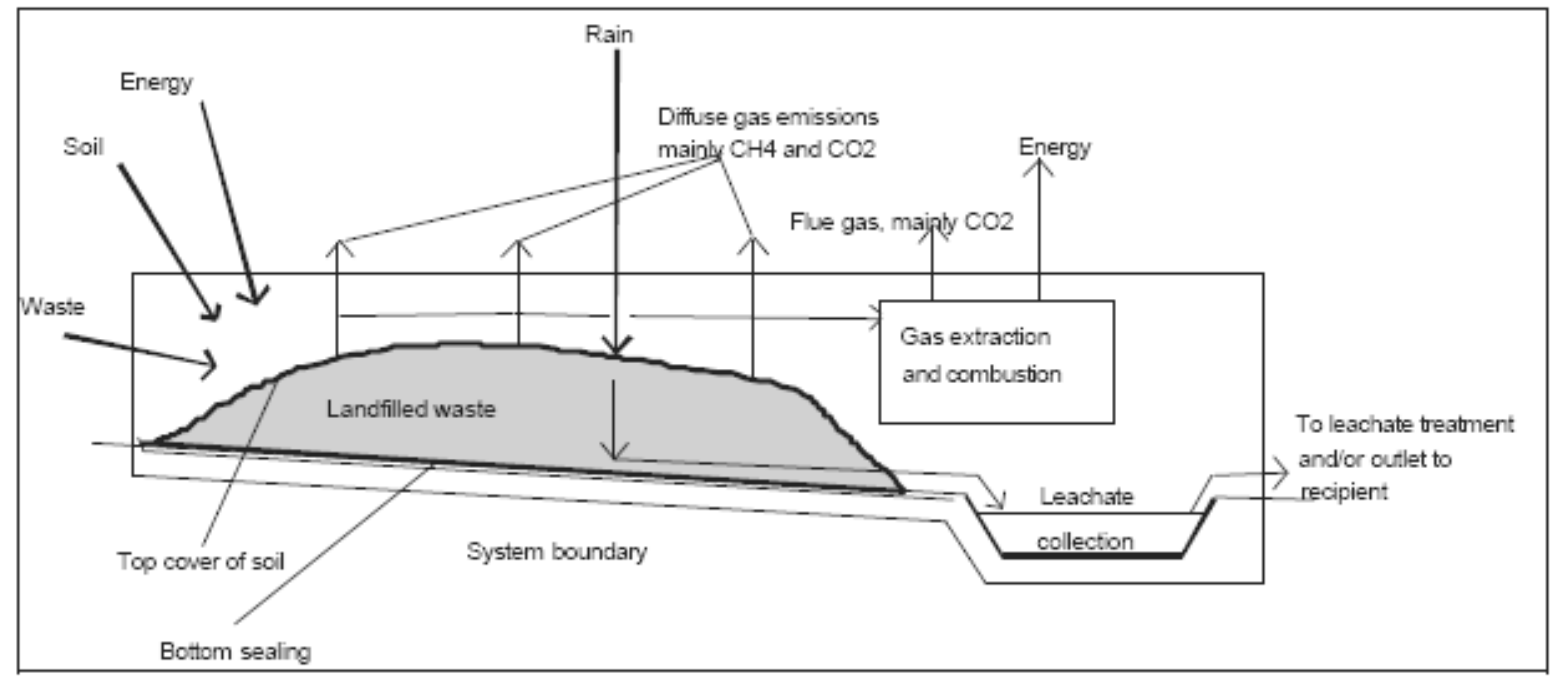

Figure 3: System boundaries of the landfill model (Bramryd. 1997).

\section{RESULTS AND DISCUSSION}

Biomass materials, i.e. paper, food and garden wastes, wood, leather, textiles, constitute $82.7 \%$ of the MSW. The rest are inorganic materials such as metals, glass, gypsum/asbestos from construction household, and other minerals. Based on table 2, the organic waste, wood and paper shows significant amount which can be categorised as the main intrusion of carbon in landfill. It is noticible that these type of waste has high amount of water content, quantified at almost $45 \%$ of all waste. This value is common in waste generated in tropical countries which generates higher amount of methane than of other areas (Agamuthu. 2010).

Table 2: Waste composition of incombustibles waste in Jeram Sanitary Landfill comprised mainly domestic waste, bulk waste and garden waste

Type of Waste

Collected Amount [tonne/day] Waste composition

(Percentage by wet weight basis, $\%)$

\begin{tabular}{lrr}
\hline Aluminium Cans & 6.5 & 0.468 \\
\hline Textile & 60.1 & 4.327 \\
\hline Debris & 10.0 & 0.720 \\
\hline Electronics & 1.5 & 0.108 \\
\hline Organic Waste & 265.4 & 19.109 \\
\hline Glass & 86.3 & 6.214 \\
\hline Hard Paper & 121.1 & 8.719 \\
\hline Soft Paper & 161.8 & 11.650 \\
\hline Hard Plastic & 136.6 & 9.835 \\
\hline Soft Plastic & 279.4 & 20.120 \\
\hline Kitchen Waste & 119.4 & 8.597 \\
\hline Metal & 0.4 & 0.029 \\
\hline PVC Pipes & 7.0 & 0.504 \\
\hline PVC Wires & 0.9 & 0.065 \\
\hline Polystyrene & 21.6 & 1.555 \\
\hline Sanitary Waste & 39.9 & 2.876 \\
\hline Footwear & 12.2 & 0.878 \\
\hline Tin/Alloy & 49.7 & 3.578 \\
\hline Wood & 9.0 & 0.648 \\
\hline
\end{tabular}


By using the ultimate (atomic) analysis of various types (Tchobanoglous et al. 1993) of wastes and the atomic weights of the respective elements Themelis NJ \& Kim HY, 2002), it was possible (to derive the composite molecular formula corresponding to mixed food wastes and paper:

Mixed food and green wastes: $\mathrm{C}_{6} \mathrm{H}_{9.6} \mathrm{O}_{3.5} \mathrm{~N}_{0.28} \mathrm{~S}_{0.2}$. Mixed paper : $\mathrm{C}_{6} \mathrm{H}_{9.6} \mathrm{O}_{4.6} \mathrm{~N}_{0.036} \mathrm{~S}_{0.01}$

It can be seen that sulfur and nitrogen are relatively minor components and occur principally in mixed and green food wastes. Also, if one excludes nitrogen and sulfur, the molecular structure of mixed paper is very close to cellulose, $\left(\mathrm{C}_{6} \mathrm{H}_{10} \mathrm{O}_{5}\right)_{\mathrm{x}}$. If one excludes the minor elements, the average molecular structure of organic compounds in MSW can be approximated by the molecular composition $\mathrm{C}_{6} \mathrm{H}_{10} \mathrm{O}_{4}$ (Themelis et al. 2002).
In the model for landfilling of household waste the different kinds of carbon are degraded at different rates. Biological carbon is divided into groups, where C-lignin is left non-degraded until remaining time (RT), C-cellulose is degraded by $70 \%$ during survayeable time period (ST) and the rest of the biological carbon, easily degradable starch, sugar, fat and protein, is totally degraded during ST. Out of the fossil carbon, like for example in plastics, $97 \%$ is left within the landfill until the remaining time (Finnveden et al. 1995).

The performance of the landfill with regard to the individual elements in the municipal solid waste was assessed by means of the transfer coefficients and the enrichment/depletion of the carbon and nitrogen elements for the landfill. An example of coefficent quantified is the enroute of carbon flow of post consumer waste, which shows more than $50 \%$ ends up in landfill, with high conversion values to carbon dioxide, $\mathrm{CO}_{2}$ and methane, $\mathrm{CH}_{4}$, as shown in figure 4.

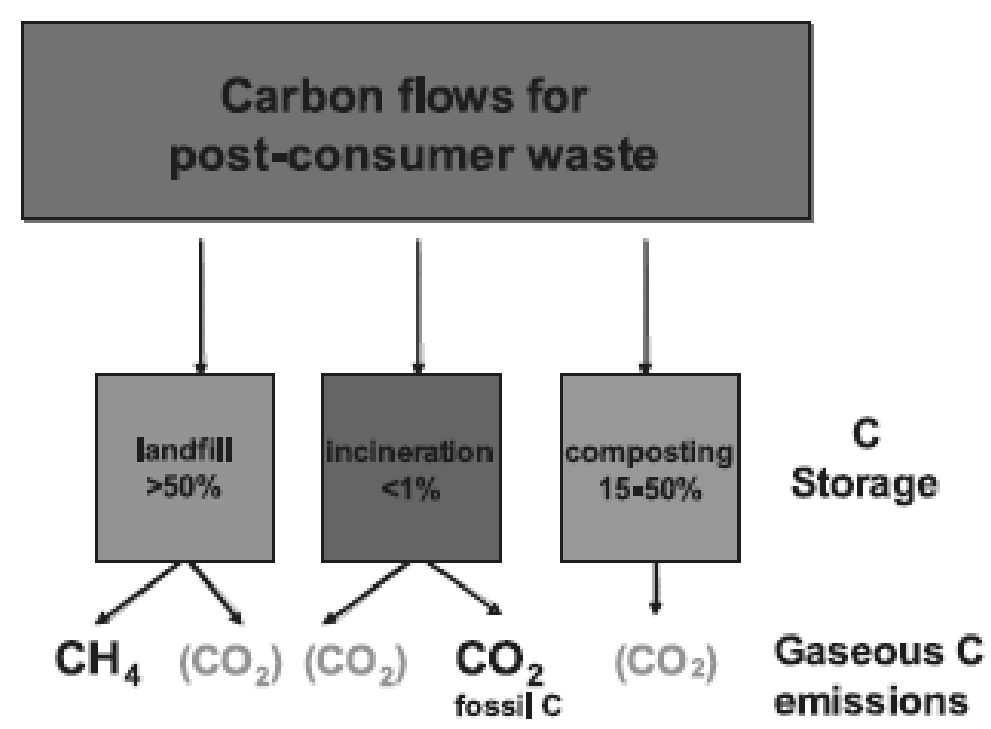

Figure 4: Carbon flows through major waste management systems including $\mathrm{C}$ storage and gaseous $\mathrm{C}$ emissions. The carbon dioxide, $\mathrm{CO}_{2}$ from biomass is not included in GHG inventories for the waste sector. (References for C storage : Huber-Humer 2004, Zinati et al. 2001; Barlaz 1998; Bramryd 1997; Bogner 1992.)

Mass-balances from field studies have indicated that approximately 1 weight- $\%$ of the degraded carbon will outflow via leachate mainly as fatty acids and similar, and 99 weight- $\%$ via the landfill gas as $\mathrm{CH}_{4}$ and $\mathrm{CO}_{2}$ (Baccini et al 1987). As a thumb rule $1 \mathrm{~g}$ of organic carbon (TOC) corresponds to $3 \mathrm{~g}$ COD. The ratio BOD/COD varies during the lifetime of the landfill. During the acid, anaerobic stage the ratio will be high, 0,1 0,8 , and during the methane stage low, <0,05 (Öman, 1991). The average ratio BOD/COD is assumed to be about 0,25 during the surveyable time period (Sundqvist et al, 1997). Carbonnitrogen coupling can substantially alter carbon cycle sensitivity (IPCC 2010). The leachate from the landfill is assumed to be purified in a municipal sewage treatment plant and sludge formed in the plant is landfilled. These processes are described below. Water percolating through landfills will pick up and transport chemicals creating leachate: a complex mixture of suspended and soluble substances. The quantity of leachate generated depends principally on rainfall and the state of the landfill. At new, unsealed landfill sites, the total 
rainfall collects as leachate. With progressive sealing leachate quantity reduces to $10-20 \%$ of total rainfall. For municipal solid waste landfills, the surveyable time period is defined as the time it takes to reach the later part of the methane phase when gas production is diminishing The integrated emissions over a 50 year period are not expected to differ largely from the emissions over a 200 year perspective. During the period 50 - 200 years the landfill is presumed to have low activity and low levels of emissions. However, the period before 50 years is characterised by a high biological activity causing a lot of methane generation and also relatively high leachage of organic materials (Sundqvist et al, 1997). After some hundred years an increased metal leachage is possible, especially if ambient air is diffusing into the landfill and increases the redox potential. Remaining Time (RT) is hypothetical infinite period are total degradation and emission of the landfilled materials. This time period is introduced to get the maximum, potential impacts form landfill emission.

The formed landfill gas contains mainly $\mathrm{CH} 4$ and $\mathrm{CO} 2$. Different organic materials give different ratios between $\mathrm{CH} 4$ and $\mathrm{CO} 2$. The collection yields have often been very low in Jeram Sanitary Landfill. According to Yamada et al. 2010, the nonrecovered gas will migrate through the soil cover, and methane-oxidising micro-organisms will oxidise a part of the methane to carbon dioxide. According to Gardner (1993), about $15 \%$ of the methane may be oxidised. Under the anaerobic conditions assumed for the surveyable time period various shares of the carbon is turned into carbon dioxide and methane depending on the origin of the carbon. During RT all fossil carbon is assumed to become $\mathrm{CO} 2$. The only methane produced during RT is derived from $40 \%$ of the remaining cellulose carbon. This is valued into flow spectrum as shown in figure 5 .

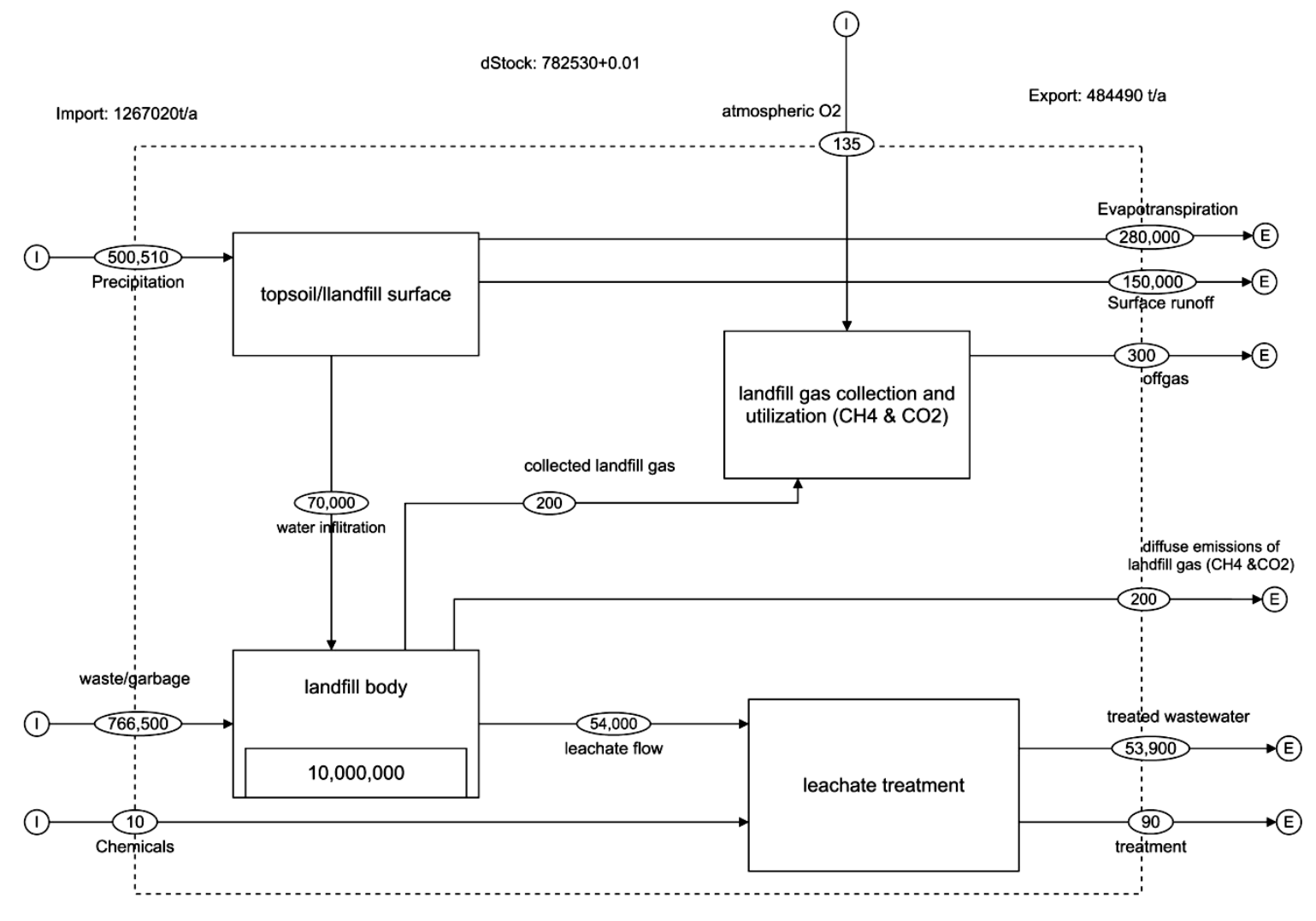

Figure 5 : Spatial system boundary for carbon flow from Jeram Landfill using STAN software

All nitrogen in the organic material was subjected to be transformed to ammonia or ammonium. The formed ammonia will be transferred to the leachate and emitted asammonical nitrogen, $\mathrm{NH}_{3} / \mathrm{NH}_{4}{ }^{+}$in the leachate. There was trace value of ammonia gas in gas outlet analysis. However, usually the analyses of ammonia in air are disturbed by interference from air nitrogen, so there is a lack of knowledge about ammonia in landfill gas. For the chosen landfills with given morphology and climate, the specific annual leachate remains nearly constant, between 5 and 10 years (Barlaz M., 1998). As precipitation is constant over this time period, the ratio leachate/precipitation has a value of 0.4 
after 5 years. According to P. Baccini et al 1987, after a mean residence time of about 10 years $(0=$ 9.4), approximately $20 \%$ of the carbon has been exported in the gas (transfer coefficient, $\mathrm{k} \sim=0.21$ ); approximately $5-6 \%$ of nitrogen and chlorine have been transferred to the leachate.

According to Huber-Humer et al (2010), $\mathrm{NH}_{4}-\mathrm{N}$ in the leachate can be significantly reduced via in-situ aeration and the leached $\mathrm{NO}_{3}-\mathrm{N}$ can not compensate the reduction of $\mathrm{NH}_{4}-\mathrm{N}$. Even at high aeration rates, there are anaerobic zones where $\mathrm{NO}_{3}-\mathrm{N}$ is denitrified to gaseous $\mathrm{N}_{2}$. Nitrogen was mainly leached in form of $\mathrm{NO}_{3}-\mathrm{N}$ after about 12 weeks of aeration.A main part of the reduced $\mathrm{NH}_{4}-\mathrm{N}$ was just transformed into $\mathrm{NO}_{3}-\mathrm{N}$. Methane, $\mathrm{CH}_{4}$ is microbially produced under strict anaerobic conditions as in landfills, while the $\mathrm{N}_{2} \mathrm{O}$ is an intermediate product of microbial $\mathrm{N}$ cycling promoted by conditions of reduced aeration, high moisture, and abundant N. Both GHGs can be produced and emitted at many stages between wastewater sources and final disposal. Landfill $\mathrm{N}_{2} \mathrm{O}$ is considered an insignificant source globally (Bogner et al. 1999, Rinne et al. 2005), but may need to be considered locally where cover soils are amended with sewage sludge (Borjesson \& Svensson 1997a) or where aerobic/ semi-aerobic landfill designs are implemented. (Tsujimoto et al. 1994). Substantial emissions of $\mathrm{CH}_{4}$ and $\mathrm{N}_{2} \mathrm{O}$ can occur during wastewater transport in closed sewers.

\section{CONCLUSION}

This study quantified carbon and nitrogen flows in sanitary landfill system. Kitchen waste and garden waste contribute significantly to the mass flow in landfill. This finally contributed to degraded organic carbon and total nitrogen and accounted for carbon and nitrogen ratio in landfill. Carbon is predominantly exported in gas form. A material balance of the waste from the different sources indicated that it is the same as the results of sampling at random. The sampling by source did give a good understanding of the waste that is generated by the different sources giving account to material flow spectrum.

For nitrogen, a small biogeochemical cycle with relatively rapid turover is coupled to a large global pool with slow turnover. For nitrogen, the major pool is found in the atmosphere The carbon and nitrogen flow related closely to the cycles in the landfill. Input from landfill are mainly waste and rainfall while major output are mainly gas and leachate. Defining stock within closed system i.e sanitary landfill as spatial system boundary for certain period of time (temporal boundary) are the main issues that differ from one country to another.

\section{ACKNOWLEDGEMENT}

Auhors would like to thank Jeram Sanitary Landfill Management for support and permission to undertake research, external consultant form Vienna Technical University,Professor Paul H. Brunner, Dr. Johann Fellner and Oliver Cencic, Dr Masato Yamada (National Institute of Environmental Studies Japan), Malaysia Meteorological Department (Rainfall Data) and University of Malaya for substantial grant support.

\section{REFERENCES}

1. Agamuthu P., Fauziah S.H., Navarani V.\& Khairuddin L. (2010) Impacts of Landfill Cover in Pollution Prevention. Eds Li.S, Wang Y., Cao F., Huang P. \& Zhang Yao. Proceedings of the 2009 International Symposium on Environmental Science and Technology Shanghai China, June 2-5 2009 in Progress in Environmental Science and Technology Vol II Part A. Science Press USA Inc. pp 823-829

2. Agamuthu P. \& S.H. Fauziah 2010 Impact of Landfill Gas on Climate Change, International Conference on Climate Change and Bioresource (ICCCB 2010) $9^{\text {th }}-12^{\text {th }}$ February 2010, Department of Biotechnology, Bharathidasan University India.

3. American Public Health Association American Water Works Association and Water Environment Federation 1998 Standard Methods for the Water and Wastewater and Examination 20th ed Washington USA.

4. Aziz Othman \& Joy Jacqueline Pereira Sustainable Development Indicators Providing Environmental Statistics for National Reporting1998 Department of Statistics, Malaysia \& Institute for Environment and Development (LESTARI), University Kebangsaan Malaysia

5. Baccini, P., Henseler, G., Figi, R. and Belevi, H. (1987); Water and element balances of municipal solid waste landfills. Waste Management and Research; 5; 483-499.

6. Baccini,P. \& Brunner,P.H.(1991) Metabolism of the Anthroposphere. Springer.Berlin 
7. Brunner PH and Dominique MS (1993) Material Balance of a Construction Waste Sorting Plant Waste Manag Res 1993; 11; 27 DOI: 10.1177/0734242X9301100104. Accessed on July 18, 2010

8. Barlaz, M. (1998) Carbon storage during biodegradation of municipal solid waste components in laboratory-scale landfills. Global Biogeochemical Cycles, 12, 373380.

9. Barlaz M, Cowie S, Staley B, Hater G (2004). Production of NMOCs and trace organics during the decomposition of refuse and waste components under anaerobic and aerobic conditions. Third Intercontinental Landfill Research symposium Nov 29th-Dec 2nd; 2004.

10. Belevi,H. 2002 Material Flow Analysis As a Strategic Planning Tool for Regional Wastewater and Solid Waste Management. Department of Water \& Sanitation in Developing Countries (SANDEC) Swiss Federal Institute for Environmental Science and Technology (EAWAG) Duebendorf.

11. Bergback, B., Johansson, K., Mohlander, U. (2001) Urban Metal flows-A case study of Stockholm. Water, Air and Oil Pollution; Focus 1,3-24

12. Bertram, M., Graedel, T.E., Rechberger, H., Spatari, S., 2002. The contemporary European Copper cycle: Waste Management Subsystem. Ecological Economics 42, 43-57.

13. Bertram, M., Martchek,K.J., Rombach, G. Material Flow Analysis in the Alumnium Industry. Journal of Industrial Ecology Blackwell Publishing 650-654

14. Binder,C.R. 1996 The Early Recognition Of Environmental Impacts of Human Activities In Developing Countries. $\mathrm{PhD}$ Dissertation 11748 Swiss Federal Institute of Technology, Zurich Switzerland.

15. Bogner, J. (1992) Anaerobic burial of refuse in landfills: increased atmospheric methane and implications for increased carbon storage. Ecological Bulletin, 42, 98-108.

16. Bolin,B. And R.B. Cook (eds) 1983. The Major Biogeochemical Cycles and Their Interactions. Wiley. New York.
17. Bogner, J., Spokas, K., \& Burton, E. (1999) Temporal variations in greenhouse gas emissions at a midlatitude landfill. Journal of Environmental Quality, 28, 277-288.

18. Borjesson, G. \& Svensson, B. (1997a) Nitrous oxide release from covering soil layers of landfills in Sweden. Tellus, 49B, 357-363.

19. Bramryd, T. (1997) Landfilling in the perspective of the global CO2 balance. In: Proc. of the Sardinia '97, International Landfill Symposium, October 1997. CISA, University of Cagliari, Sardinia.

20. Bringezu, S. , Fischer-Kowalski, M., Kleijn,R. \& Palm,V. (1997) Regional and National Material Flow Accounting: From Paradigm to Practise of Sustainability. Proceedingsof the ConAccount Workshop 21-23 January 1997 Leiden The Netherlands

21. Brunner, P.H., \& Rechberger,H. (2004) Practical Handbook of Material Flow Analysis. CRC Press LLC, Boca Raton, Florida. 337-338

22. Cencic, O. \& Rechberger, H. (2008) Material Flow Analysis with Software STAN Journal of Environ. Eng. Management 18 (1),3-7

23. Department of Statistics (DoS) 2010. Compendium of Environment Statistics Malaysia 2009. Department of Statistics, Putrajaya.

24. Gardner N., Manley B.J.W., and Pearson, J.M.,(1993) Gas emissions from landfills and their contributions to the global warming. Applied Energy 44:2, 165-174

25. Graedel, T.E., Bertram, M., Fuse, K., Gordon, R.B., Lifset, R., Rechberger, H., Spatari, S., 2002. The Contemporary European Copper Cycle: The Characterization Of Technological Copper Cycles. Ecological Economics 42, 9-26.

26. Göran Finnveden, Jessica Johansson, Per Lind \& Åsa Moberg Special Report Life Cycle Assessments of Energy from Solid Waste (2000) Stockholm University Sweden 214 pp

27. Huber-Humer, M., Paola Huber P.,Gamperling, O. (2010) The fate of 
nitrogen relating to in-situ aeration of landfills. Proceedings From Sanitary to Sustainable Landfilling-why, how and when ? $1^{\text {st }}$ International Conference on Final Sink 23rd-25th September 2010 Vienna

28. Huber-Humer, M. (2004) Abatement of Landfill Methane Emissions by Microbial Oxidation in Biocovers Made of Compost. $\mathrm{PhD}$ Thesis, University of Natural Resources and Applied Life Sciences (BOKU), Vienna.

29. IPCC 2009 Working Group 1 Contribution to the Fifth Assessment Report. Climate Change 2013 The Physical Science Basis. $31^{\text {st }}$ Session of the IPCC, Bali, Indonesia, 26-29 October 2009

30. Kjeldsen, P.I., Barlaz M. A., . Rooker A. P., Baun A., Ledin A., and Christensen T. H., 2002. Present and Long-Term Composition of MSW Landfill Leachate: A Review. Critical Reviews in Environmental Science and Technology, 32(4):297-336.

31. Laura S., Riina A. \& Pekka K. 2004 Flow Of Nitrogen And Phosphorus In Municipal Waste: A Substance Flow Analysis In Finland. Journal of Industrial Ecology $1,165-186$

32. MFA Manual Guidelines for the use of Material Flow Analysis for Municipal Solid Waste (MSW) Management 2000 Aid in the Management and European Comparison of Municipal Solid Waste Treatment Methods for a global and Sustainable Approach (AWAST Project)

33. Montagero,A., Anh,N.V.,Luthi,C.,Schertenleib,R.Belevi, H. (2006) Building The Concept Of Material Flow Analysis Into The Household-Centred Environmental Sanitation Planning Approach. Proceedings of the Conference on Renewed Efforts to Plan for Sustainable Development. European Academy for the Urban Environment and Technical University Berlin, Germany.

34. Matsube Y. K., Kubo H., Nakajima, K. \& Nagasaka T., Material Flow Analysis of Phosphorus in Japan: The iron and steel industry as a major phosphorus Source. Journal of Industrial Ecology Blackwell Publishing 650-654
35. Maznorizan Mohamad, Siniarovina Urban, Siva Shangari \& Toh Ying Ying (2010) The Status of Acid Deposition in Malaysia Based on Malaysian Meteorological Department (MMD) Data Analysis from 1994 - 2008 Ministry of Science Technology and Innovation \& Malaysian Meteorological Department

36. Ministry of Science, Technology and Environment (MOSTE), 2000. Malaysia Initial National Communication. pp. 131.

37. Öman, C.(1991) Conversion Phases in Municipal Landfill IVL Report No B1017; IVL, Stockholm, Sweden; 1991.

38. P. Baccini, G. Henseler, R. Figi and H. Belevi (1987) Water and Element Balances of Municipal Solid Waste Landfills. Waste Manag Res 1987; 5; 483 DOI: $\quad 10.1177 / 0734242 X 8700500162$ Accessed on July 18, 2010

39. Rinne, J., Pihlatie, M., Lohila, A., Thum, T., Aurela, M., Tuovinen, J-P., Laurila, T., \& Vesala, R. (2005) N2O emissions from a municipal landfill. Environmental Science and Technology, 39, 7790-7793.

40. Sivapalan K, Kamaruzzaman S, Muhd Noor MY, Abd Halim S, \& Rakmi AR (2002) A Material Balance of the Municipal Solid Waste Generated by the Various Sources in Kuala Lumpur World Engineering Congress 2002, Kuching Sarawak, July 22-25 2002

41. Sprent,J.I. (1988) The Ecology of Nitrogen Cycle. Cambridge University Press,Cambridge

42. Spaun, S (1995) Comparison Of The Mass Balances Of Residual Waste Landfill And Incinerator Residue With Special Regard To Water Balance. Diploma Thesis. Institute for Water and Waste Management Vienna Vienna Technical University.

43. Sundqvist, J.-O., Finnveden, G., Albertsson, A.-C., Karlsson, S., Berendson, J., Höglund,

44. L.O. (1997) Life Cycle Assessment and Solid Waste - Stage 2. AFR Report 173; AFR, Stockholm, Sweden.

45. Sundqvist, J.-O. (1999) Life cycles assessments and solid waste - Guidelines for solid waste treatment and disposal in 
LCA Afr-Report 279.Swedish Environmental Protection Agency Stockholm, Sweden .

46. Tchobanoglous $\mathrm{G}$, Theisen $\mathrm{H} \&$ Vigil $\mathrm{S}$ (1993) . Integrated solid waste management., Chapter 4. New York: McGraw- Hill

47. Tchobanoglous, G and P.R. O’ Leary 1994. Landfiling. In: Kreith,F. [Ed.] Handbook of Solid Waste Management.McGraw Hill, New York.P.12.1-12.8.

48. Themelis NJ \& Kim HY (2002). Material and energy balances in a large-scale aerobic bioconversion cell. Waste Manage Res 2002;20:234-42.

49. Themelis NJ \& Ulloa PA (2006). Methane generation in landfills

50. Tsujimoto, Y., Masuda, J., Fukuyama, J., \& Ito, H. (1994) N2O emissions at solid waste disposal sites in Osaka City. Air Waste, 44, 1313-1314.

51. Wollast, R. 1981. Interactions between major biogeochemical cycles in marine ecosystems. pp.125-142. In G.E. Likens (ed.) Some Perspectives of the Major Biogeochemical Cycles. Wiley,New York.

52. Yamada M., Ishigaki T., Tachio K., Inoue Y. (2003) Carbon flow and landfill methane emission in Japanese industrial waste stream. 9th Int.Waste Management Landfill Symposium Proceedings S. Margherita di Pula, Cagliari, Italy; 6 - 10 October 2003

53. Zinati, G.M., Li, Y.C., \& Bryan, H.H. (2001) Utilization of compost increases organic carbon and its humin, humic, and fulvic acid fractions in calcareous soil. Compost Science \& Utilization, 9, 156162. 